\title{
Rancang Bangun Web Scraping Pada Marketplace di Indonesia
}

\author{
Designing a Web Scraping Marketplace in Indonesia \\ Afrizal Aziz Maulana ${ }^{1}$, Ajib Susanto ${ }^{2}$, Desi Purwanti K. ${ }^{3}$ \\ 1,2,3 Teknik Informatika, Fakultas Ilmu Komputer, Universitas Dian Nuswantoro \\ e-mail: ${ }^{1}$ afrizalaziz19@gmail.com , ${ }^{2}$ ajib.susanto@dsn.dinus.ac.id , \\ 3desi.purwanti@dsn.dinus.ac.id
}

\begin{abstract}
Abstrak
E-commerce dan marketplace berkaitan dengan sistem dropship. Dropship merupakan istilah dari jual beli dimana drop shipper (pengecer) tidak memiliki barang. Drop shipper kini masih menggunakan cara manual dalam mendapatkan data barang dari supplier dan unggah yaitu dengan mengambil data barang secara satu persatu dan mengunggah manual satu persatu yang membutuhkan waktu cukup lebih. Pada penelitian ini dibangun aplikasi terbaru untuk membantu drop shipper dalam mendapatkan data produk dan mengunggahnya secara otomatis. Pengembangan sistem yang digunakan adalah waterfall dengan alur proses dari analisis kebutuhan, perancangan sistem, implementasi sistem, pengujian dan pemeliharaan sistem. Penelitian ini menghasilkan sebuah aplikasi yang dapat mengambil data / scraping barang pada sebuah toko supplier yang kemudian mendapatkan hasil pengambilan data dalam bentuk .csv. Kemudian dilakukan proses unggah secara otomatis dengan hanya memasukkan nama file hasil pengambilan data yang berformat .csv, maka data otomatis terunggah ke toko drop shipper. Hasil pengujian web scrapping berhasil dilakukan dengan mengambil data produk dari marketplace Tokopedia, Shoopee dan diunggah ke e-commerce Afrizal22hop.
\end{abstract}

Kata kunci : Marketplace, E-commerce, Dropship, Drop shipper, Web Scraping

\begin{abstract}
E-commerce and marketplace related to dropship systems. Dropship is a buying and selling term where the drop shipper does not have goods. Drop shipper is still using manual methods to get goods data from suppliers and uploads by taking data items one by one and uploading them manually one by one which requires more time. In this study the latest application was built to help drop shipper in getting product data and upload it automatically. System development used is waterfall with process flow from needs analysis, system design, implementation system, testing and maintenance system. This research produces an application that can retrieve data / scraping goods at a supplier's store which then gets the results of data collection in the form of .csv. Then the upload process is done automatically by only entering the name of the file that was retrieved from the .csv format, then the data is automatically uploaded to the drop shipper shop. The results of web scrapping testing were successfully carried out by retrieving product data from the Tokopedoa, Shoopee marketplace and uploading to Afrizal22hop e-commerce.
\end{abstract}

Keyword : Marketplace, E-commerce, Dropship, Drop shipper, Web Scraping

\section{PENDAHULUAN}

Indonesia memiliki populasi pengguna intenet sebanyak 269 juta jiwa [1]. Pemanfaatan dan penggunaan internet yang semakin meluas dalam berbagai lini aktivitas kegiatan kehidupan manusia memiliki dampak signifikan pada kehidupan keseharian 
seperti kebutuhan akan komunikasi, pencarian informasi, transaksi perdagangan, dan keperluan-keperluan lainnya. Suatu cara yang dilakukan untuk kegiatan perekonomian dengan menggunakan infrastuktur internet dengan jangkauan yang sangat luas dan memiliki segmentasi penerapan yang sangat luas contohnya adalah e-commerce [2]. Indonesia juga memiliki lingkungan ideal untuk perkembangan perdagangan dengan sistem e-commerce.

Elektronik Commerce (e-commerce) merupakan suatu proses pembelian, pejualan atau pertukaran produk, informasi dan jasa melalui jaringan komputer yaitu internet. $E$ commerce merupakan perkembangan teknologi dalam bidang ekonomi [3]. E-commerce merupakan sebuah sistem manajemen inventori otomatis yang di dalamnya meliputi kegiatan transfer dana secara elektronik, pertukaran dan pengumpulan data [4]. Ecommerce berkembang secara pesat di Indonesia, bahkan perkembangannya menyebar hingga marketplace. E-commerce dan marketplace mempunyai sistem kerja yang sama tetapi terdapat perbedaan di dalamnya, e-commerce hanya terdapat satu toko sedangkan marketplace terdapat lebih dari satu toko. Marketplace[5] merupakan salah satu media online berbasis internet (web based) tempat dimana antara penjualan dan pembeli melakukan kegiatan bisnis dan transaksi secara online [6].

Marketplace sebuah tempat yang terdapat banyak supplier yang menjual barangnya secara online, sedangkan e-commerce hanya terdapat satu supplier yang menjual barang secara online [7]. Dunia e-commerce dan marketplace juga saling berkaitan dengan sistem drop ship. Drop ship merupakan sebuah konsep yang sangat penting pada dunia e-commerce dan marketplace, drop ship merupakan istilah dari jual beli dimana drop shipper (pengecer) tidak memliki barang [8]. Supplier sebagai pihak produsen atau grosir yang nantinya akan mengirimkan barangnya secara langsung kepada pelanggan yang membeli barang. Keuntungan diperoleh dari selisih harga yaitu antara harga grosir dan harga eceran [9].

Sistem drop ship mempunyai cara kerja yang sederhana, hanya mengambil data produk dari supplier dan memposting dari lapak supplier ke lapak drop shipper. Banyak drop shipper yang masih menggunakan cara manual untuk sistem drop ship. Dengan cara manual membutuhakan waktu 5 menit untuk mengambil 1 data produk dan memposting dari lapak supplier ke lapak drop shipper. Sistem yang masih manual dapat menghambat drop shipper untuk mendapatkan data produk karena membutuhkan waktu lebih lama sehingga kurang efektif. Selama waktu 8 jam drop shipper hanya mampu mengambil dan memposting 100 produk. Untuk itu, drop shipper membutuhkan alat bantu untuk mendapatkan data produk dalam sekala besar dan dapat memposting produk secara otomatis.

Web scraping [10] merupakan proses pengambilan informasi dari website yang ada atau teknik menggali informasi dari sebuah website secara otomatis. Web scraping menerapkan pengindekan dengan cara menelusuri dokumen-dokumen $H T M L$ dari suatu website yang akan diambil informasinya untuk di-tag ke HTML agar bisa mendapatkan informasi yang diambil untuk ditirukan pada aplikasi web scraping yang akan dibuat [11]. Web scraping merupakan salah satu alat bantu untuk drop shipper mendapatkan data produk dalam sekala besar dan memposting secara otomatis. Diterapkannya teknologi web scraping dan auto upload pada marketplace, diharapkan para drop shipper dapat terbantu sehingga drop shipper yang ingin membuka usaha dengan cara berjualan online dan masih mendapat kendala pada modal usaha, dapat memulai usaha dengan menggunakan web scraping untuk mendapatkan modal tambahan dan mempelajari cara kerja pada marketplace. 
Pada penelitan sebelumnya yang dilakukan oleh Shikha Mahajan dan Nikhit Kumar dalam jurnal yang berjudul "A Web scraping Approach in Node.js", membahas bahwa sebuah web scraping dapat diterapkan untuk mengambil gambar, tabel dan informasi lainnya dari situs web. Metode ini dapat ditingkatkan untuk menangani pengulangan tak terbatas saat menggunakan link untuk melintasi website. Dalam beberapa kasus teknologi web scraping mungkin satu-satunya solusi yang bisa diterapkan ketika ingin mengumpulkan data secara besar [12]. Sementara Priyanto [13] memanfaatkan web scraping untuk mendapatkan informasi yang akurat mengenai hidroponik. Sedangkan untuk waktu pengambilan data pada web scraping tergantung pada bandwith yang dimiliki server dan response time dari e-commerce/marketplace [14] yang menjadi target. Keuntungan web scraping adalah efisiensi waktu, memungkinkan pengumpulan data secara teratur dengan interval waktu yang singkat, pengurangan biaya dan jumlah informasi yang di dapat lebih banyak [15].

Dari beberapa penggunaan web scaping pada penelitian terdahulu pada penelitian ini diusulkan membangun kerangka kerja dalam membantu pekerjaan drop shipper dengan menggabungkan perkembangan teknologi dan perkembangan ekonomi saat ini. Perancangan web scraping data pada marketplace adalah salah satu solusi yang dapat berfungsi untuk memudahkan drop shipper mendapatkan data produk atau mendapatkan supplier dalam sekala besar, sehingga drop shipper tidak kekurangan data produk yang akan dijual pada lapak drop shipper dan mempunyai waktu yang efektif.

\section{METODE PENELITIAN}

Metode pengembangan sistem pada penelitian ini menggunakan metode pengembangan sistem Waterfall. Pada metode Waterfall ini memiliki beberapa aktivitas yaitu : analisis kebutuhan, perancangan sistem, implementasi sistem, pengujian sistem dan pemeliharaan. Berikut ini gambar metode Waterfall :

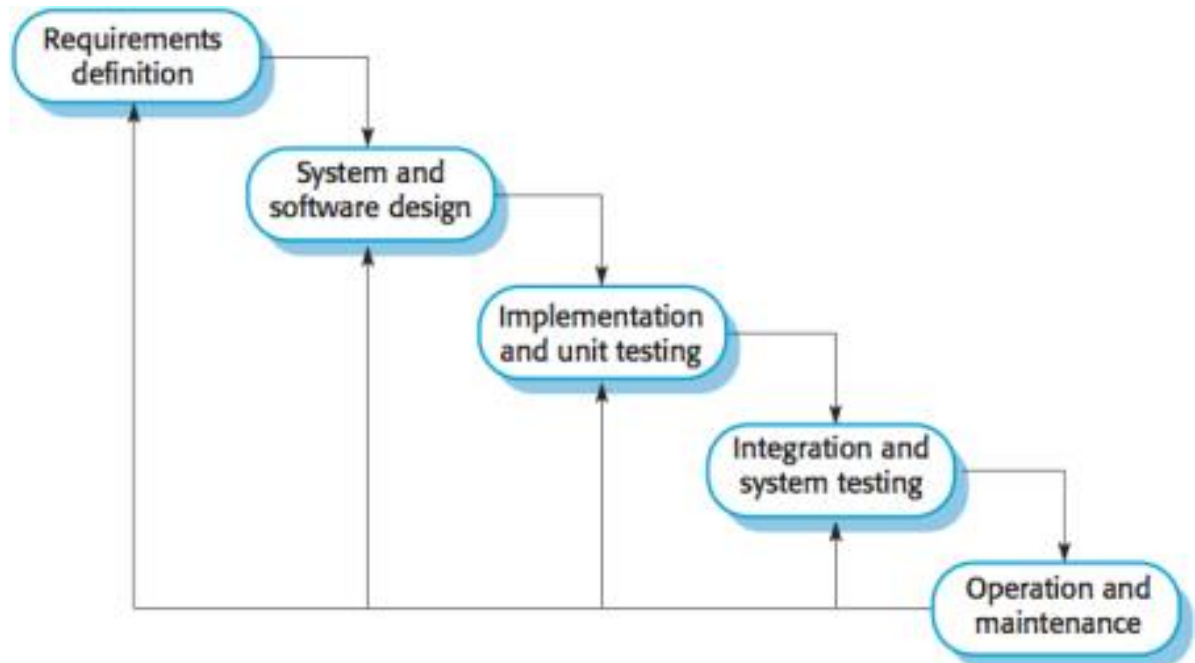

Gambar 1: Waterfall model[16]

\section{HASIL DAN PEMBAHASAN}


Pengembangan web scraping dan auto upload pada marketplace menggunakan framework laravel. Salah satu kelebihan dari framework laravel adalah mudah dalam penggunaanya, open source dan ter-maintenance setiap tahunnya. Sedangkan untuk auto upload, digunakan framework laravel dengan komponen laravel dusk[17] karena digunakan untuk menampilkan auto upload yang bekerja secara otomatis dengan menggunakan google chrome. Laravel dusk juga dibuat berdasarkan open source tool Chrome Driver dan Facebook PHP web driver sehingga dapat melakukan pengujian yang berjalan di browser.

\subsection{Desain Arsitektur Aplikasi}

Berikut ini adalah gambaran dari model kerangka kerja web scraping dan auto upload pada marketplace dan e-commerce :

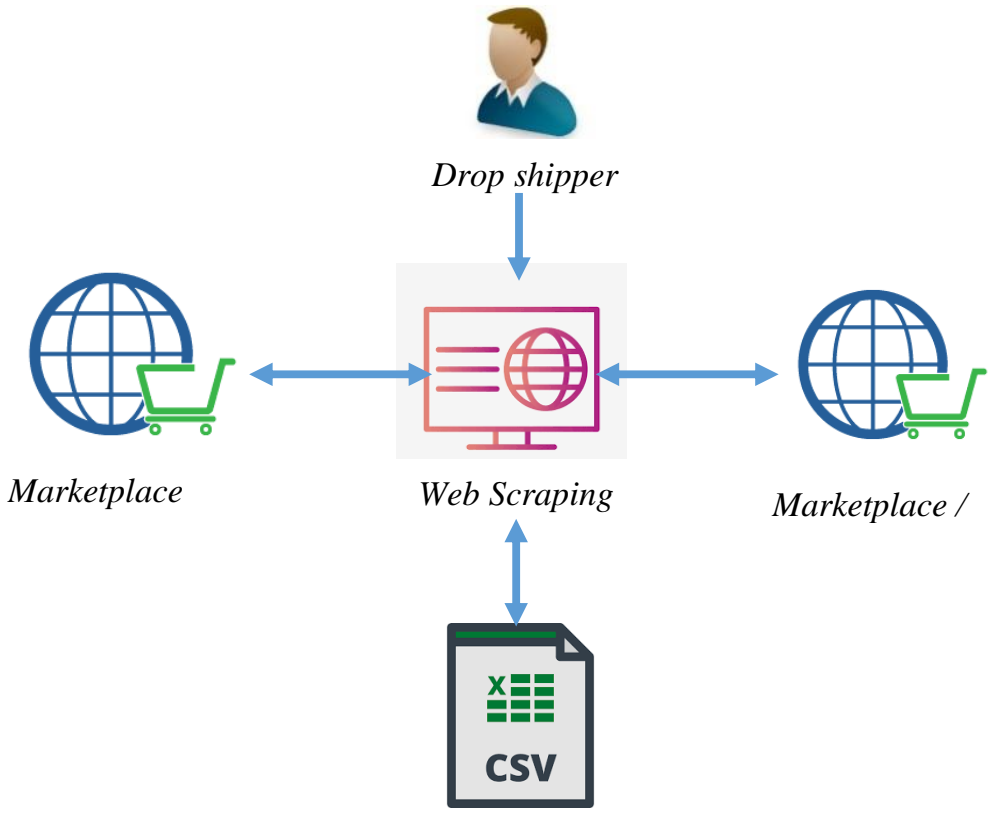

Gambar 2 : Desain Arsitektur Web Scraping

Dari gambar 2 di atas dapat dijelaskan bahwa proses web scraping dan auto upload diawali dengan pengguna / drop shipper mengakses web scraping, kemudian mencari link supplier di marketplace, selanjutnya akan dilakukan scraping data produk yang hasilnya disimpan ke dalam file berformat . $s s v$, pengguna dapat melakukan perubahan data jika menginginkannya, selanjutya dilakukan posting/upload data .csv ke target marketplacele-commerce lainnya.

\subsection{Perancangan Sistem}

Pemodelan sistem pada pengembangan sistem ini menggunakan UML (Unified Modeling Language), berikut diagram web scraping dan auto upload pada marketplace dan e-commerce :

\section{Use Case Diagram}

Dalam web scraping dan auto upload pada marketplace ini pengguna yang terlibat hanya satu yaitu pengguna drop shipper. Gambar 3 berikut ini menjelaskan akses pengguna drop shipper : 


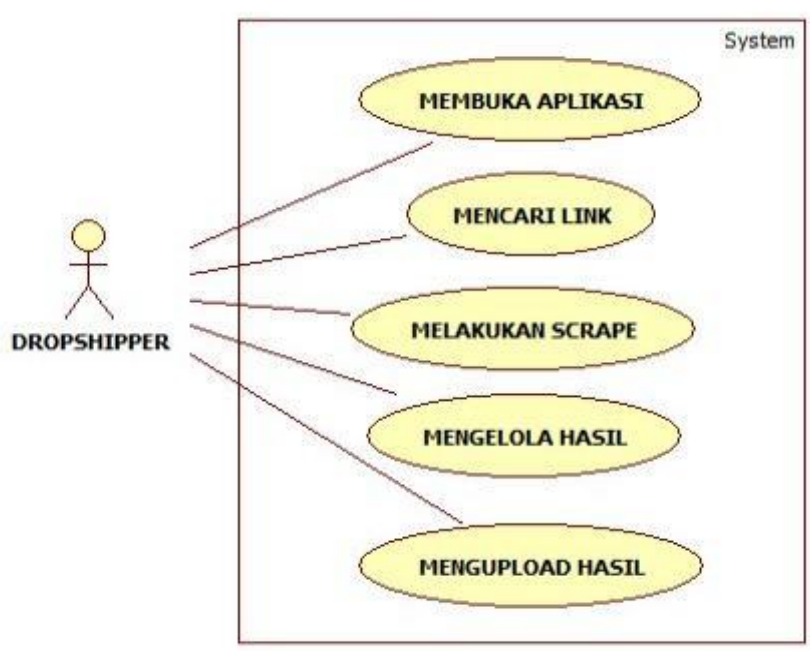

\section{Class Diagram}

Gambar 3. Use Case Diagram

Dalam web scraping dan auto upload pada marketplace terdapat 4 class yang saling berhubungan yaitu class dropshipper, supplier, scrape dan upload. Semua class yang digunakan memiliki hubungan association, artinya class satu dapat mempengaruhi class lainnya. Gambar 4 menjelaskan class diagram aplikasi web scraping dan auto upload pada marketplace

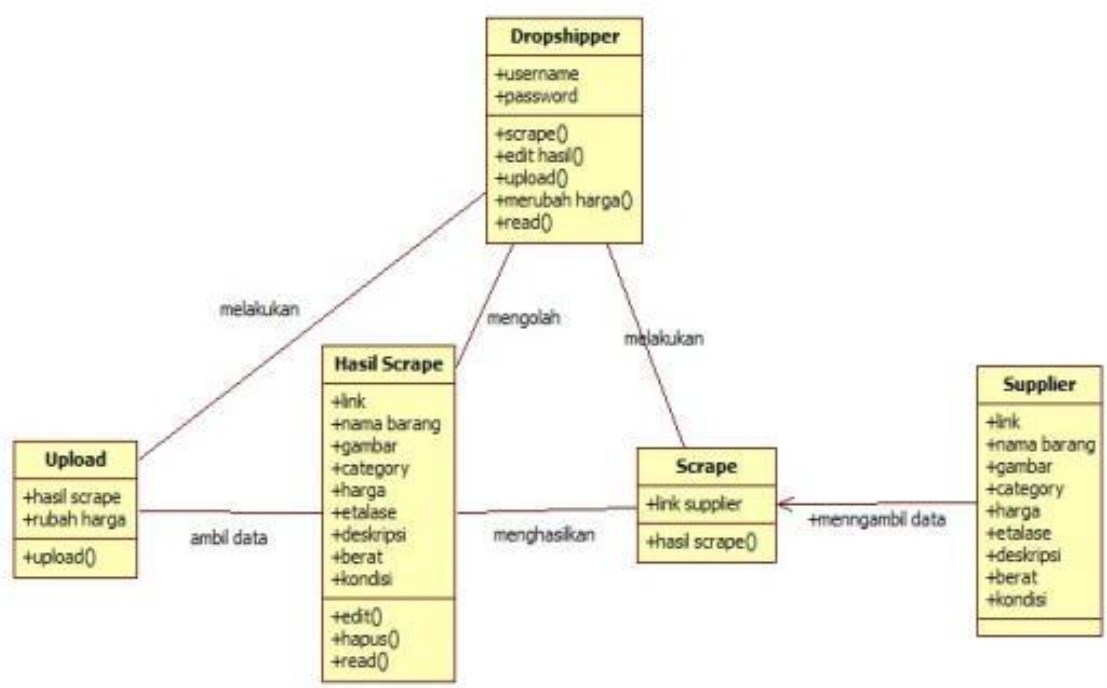

\section{Activity Diagram}

Gambar 4. Class Diagram

Berikut ini activity diagram yang menjelaskan aktivitas-aktivitas drop shipper/pengguna yang dilakukan pada web scraping dan auto upload pada marketplace. Aktivitas melakukan scrape dan meng-upload hasil scrape.

Pada gambar 5 menjelaskan proses scrape dari marketplace yang dipilih sampai menghasilkan file .csv yang merupakan hasil pengambilan data dari marketplace. Setelah file .csv diperoleh drop shipper dapat mengolahnya jika menginginkan perubahan dibeberapa bagian seperti nama produk, harga dan lainnya, selanjutnya file .csv dapat diunggah di e-commerce atau marketplace lain, gambar 6 merupkan activity diagram untuk proses auto upload. 


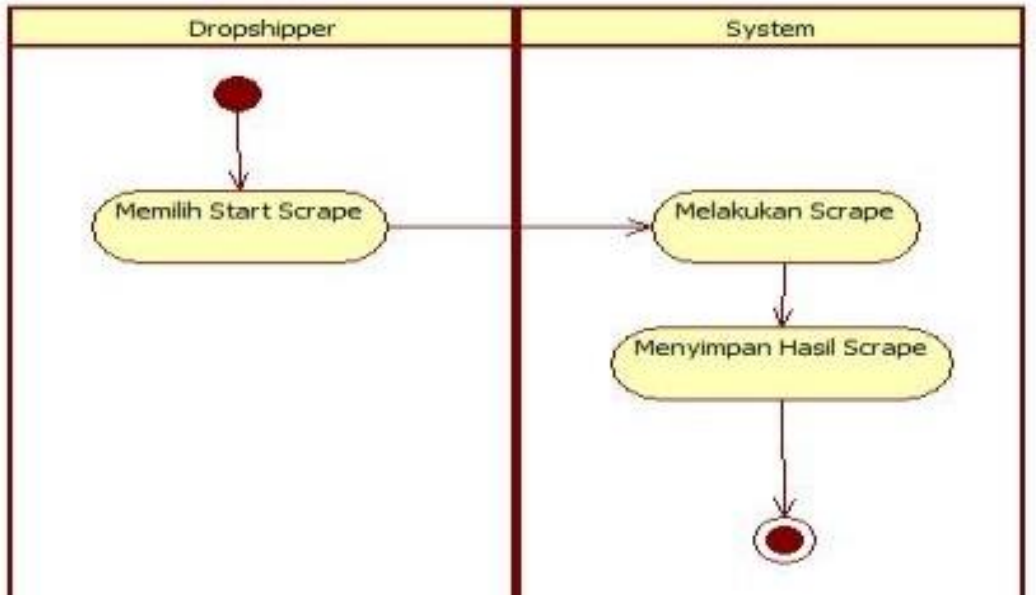

Gambar 5. Activity Diagram Melakukan Scrape

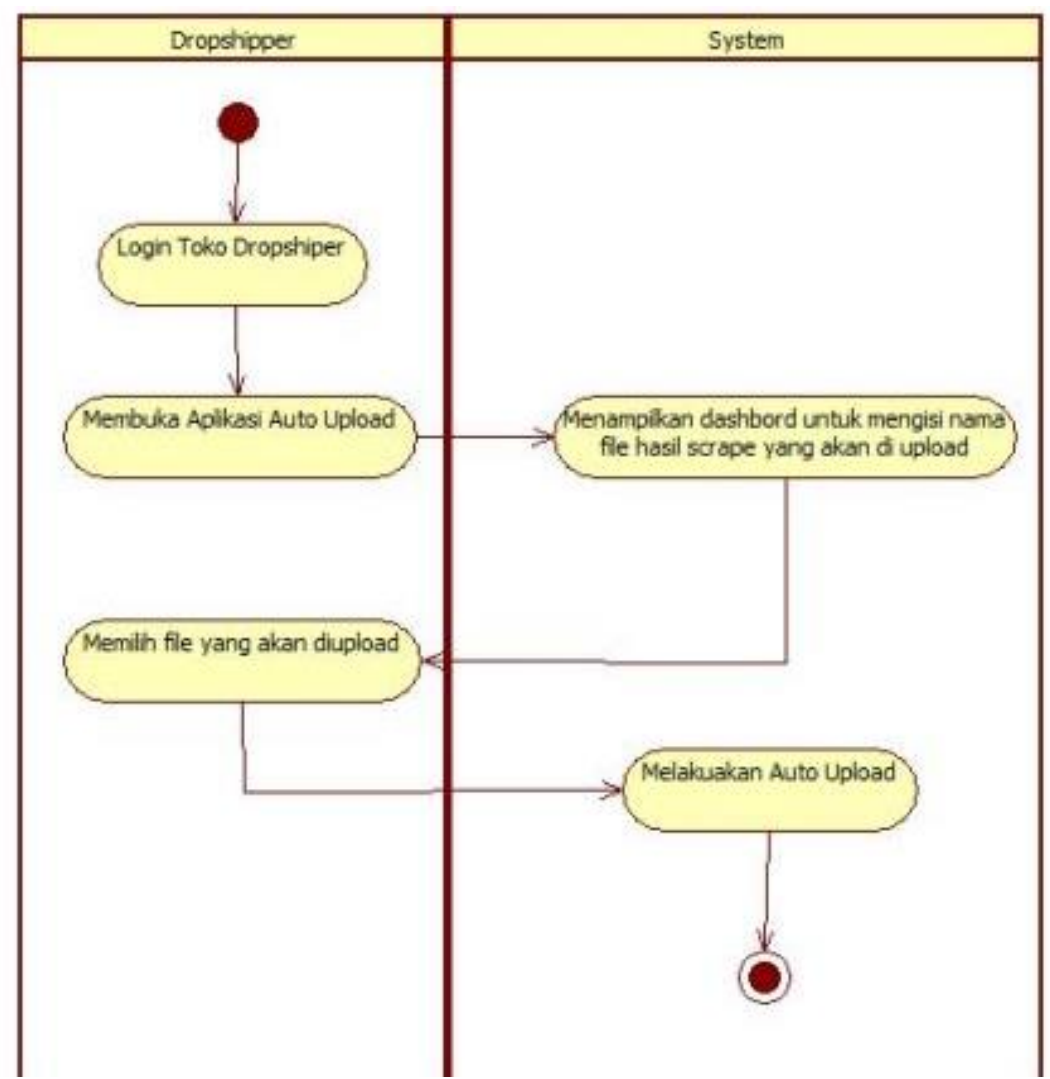

Gambar 6. Activity Diagram meng-upload hasil scrape

\subsection{Implementasi Sistem}

Berikut ini adalah tampilan dari implementasi sistem web scraping dan auto upload pada marketplace:

1. Halaman Utama

Hasil implementasi halaman utama menampilkan fasilitas untuk memilih scrape atau post untuk pengguna yang akan memakai aplikasi ini. 


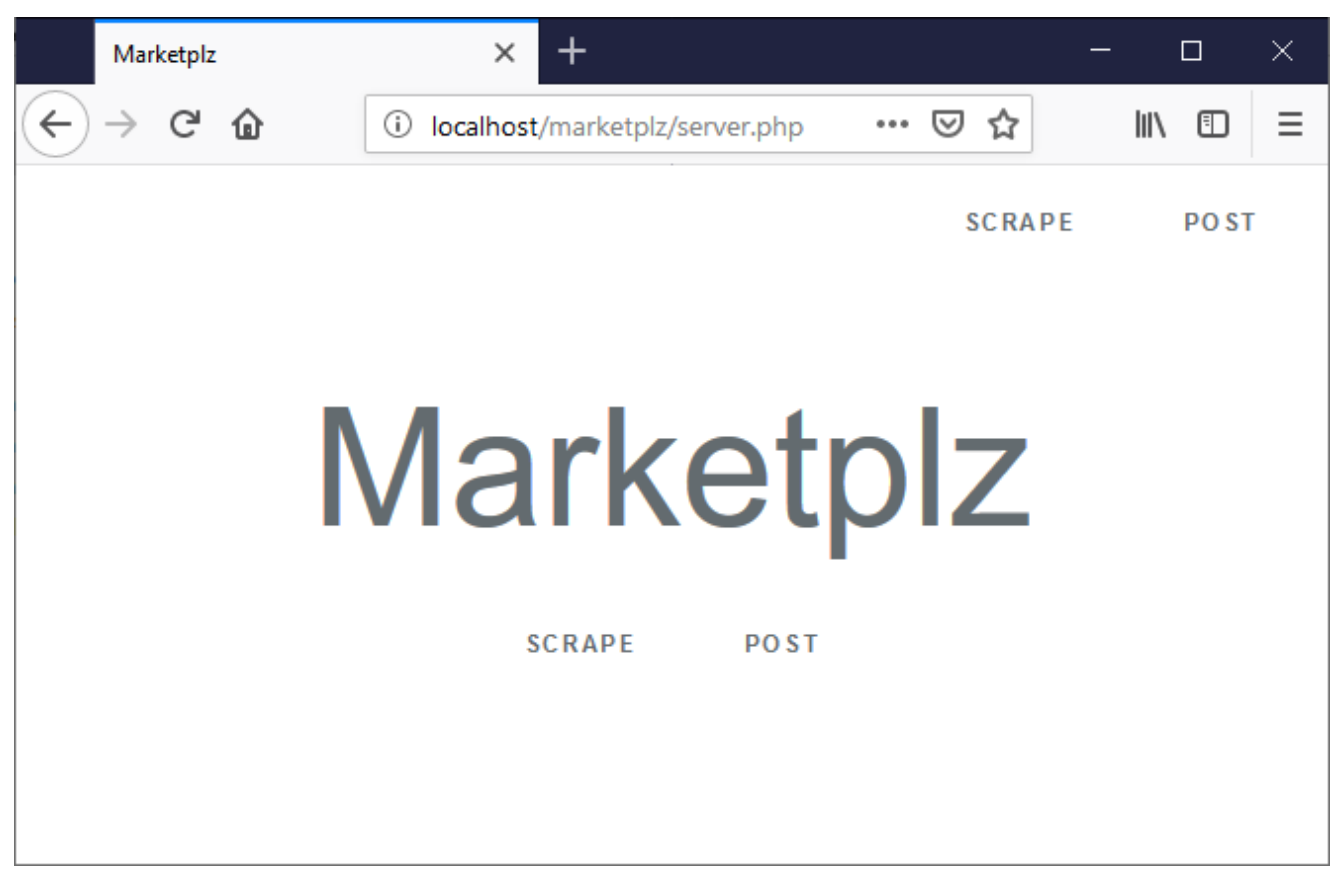

Gambar 7: Halaman Utama Web Scraping

\section{Halaman Scrape}

Halaman scrape berfungsi untuk memasukkan link / url toko supplier yang akan discrape.

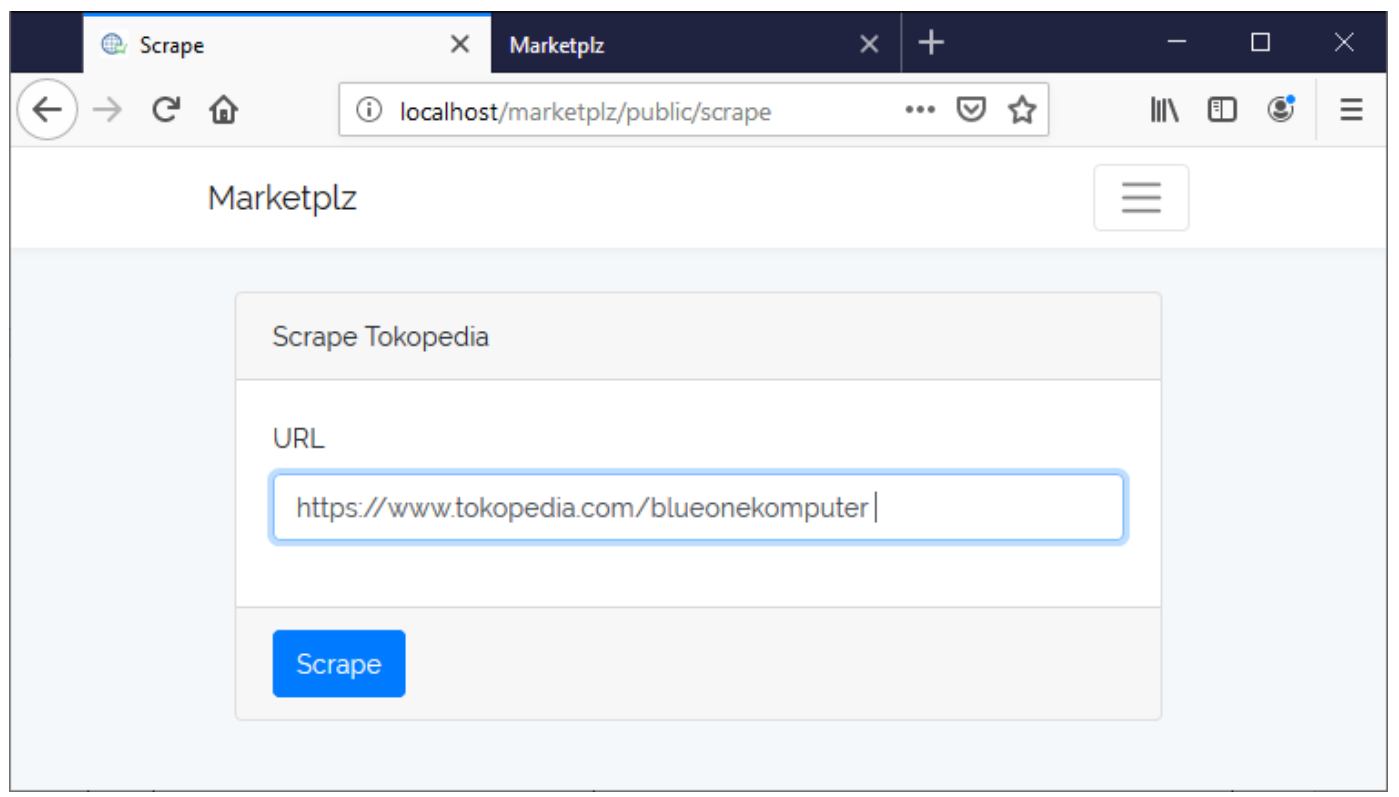

Gambar 8: Halaman Scrape

\section{Halaman Post}

Halaman post berfungsi untuk auto upload hasil scrape ke toko drop shipper yang terdapat pada marketplace. Halaman ini memiliki fitur untuk merubah harga / menaikkan harga sesuai keinginan drop shipper. 


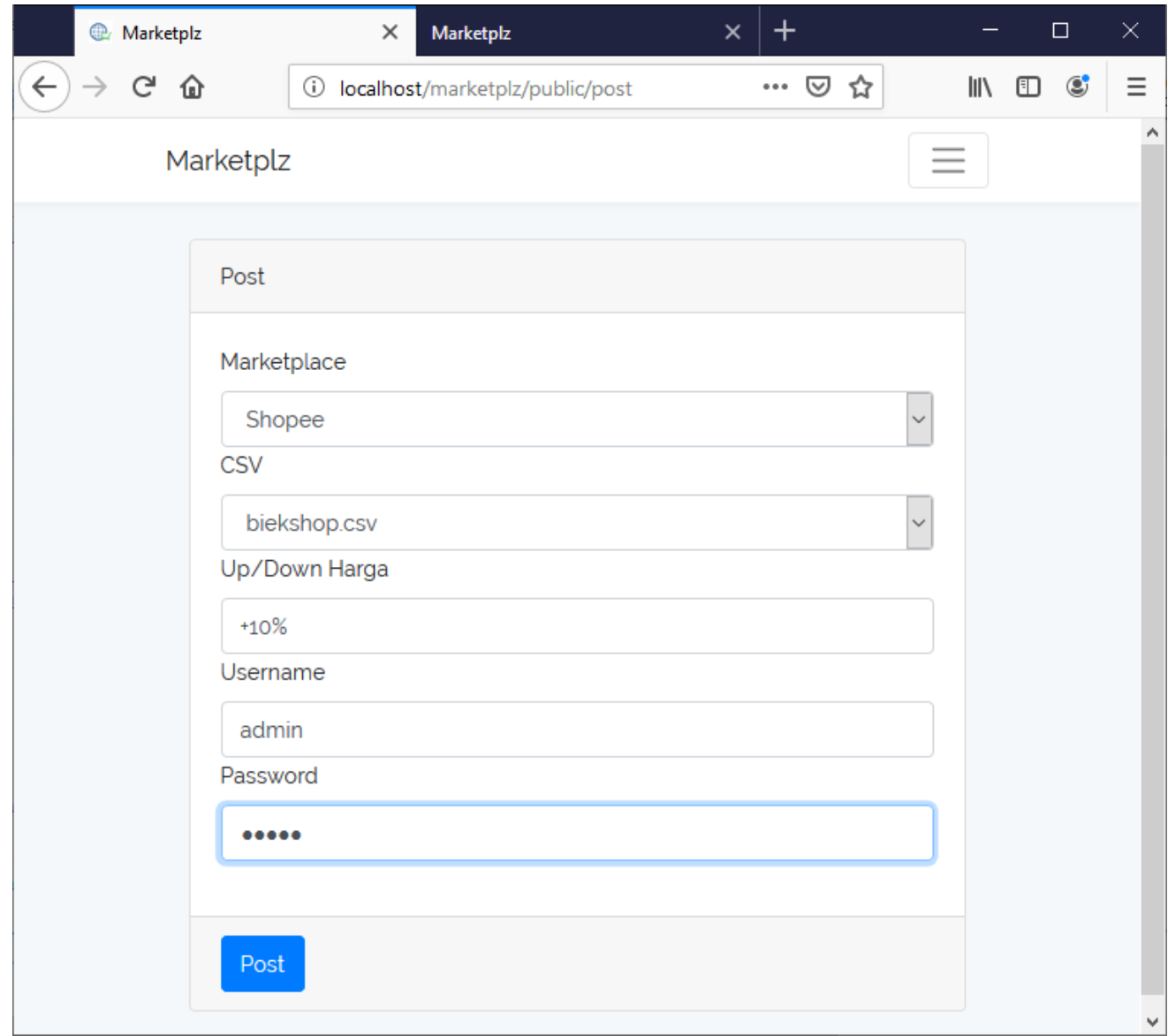

Gambar 9: Halaman Auto Upload / Post

\section{Halaman Log Proses Scrape}

Halaman ini berfungsi menampilkan log pada saat scrape dan upload. Halaman ini menampilkan berhasil atau tidaknya proses scrape data barang dari toko supplier.

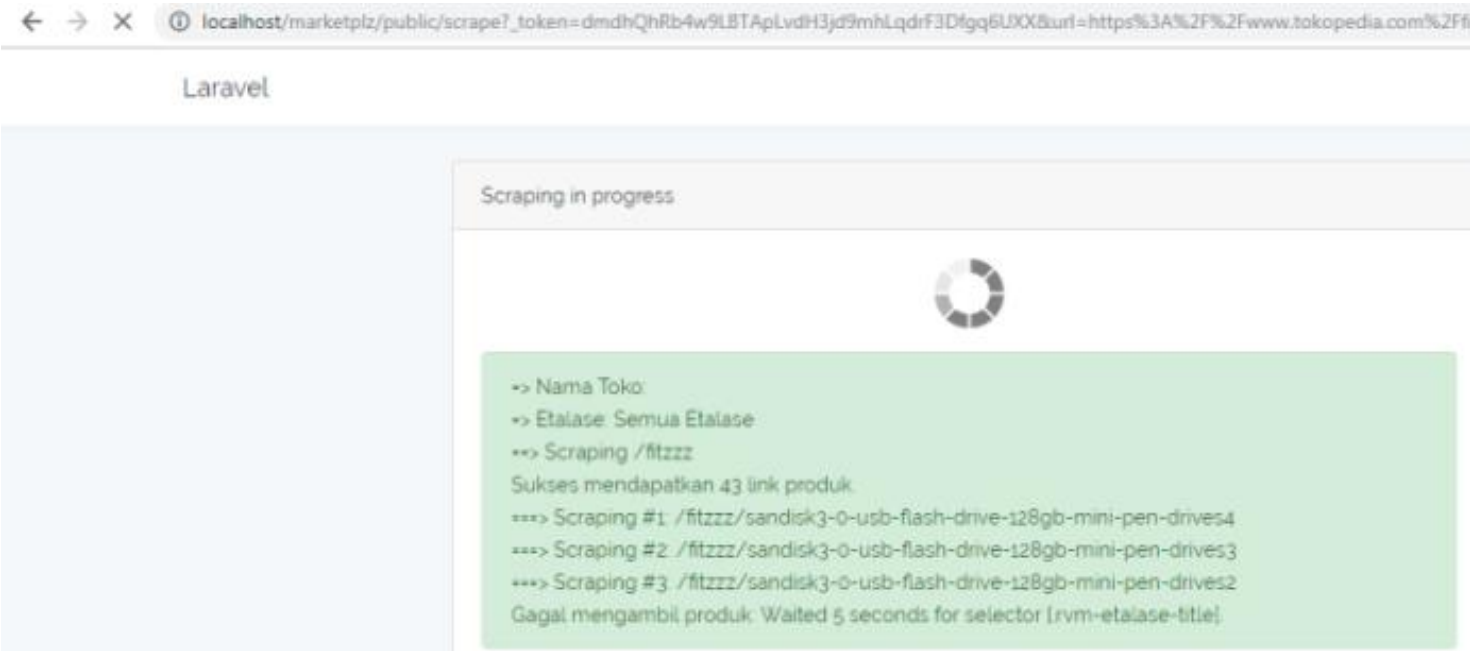

Gambar 10: Halaman Log Proses Scrape 


\subsection{Pengujian Sistem}

1. Pengujian Scrape

Pengujian ini dilakukan dengan menggunakan 10 link toko yang dijadikan supplier pada marketplace Tokopedia.

Tabel 1. Pengujian Scrape

\begin{tabular}{|c|c|c|}
\hline No & Link Supplier & Hasil File.Csv \\
\hline \multirow[t]{2}{*}{1} & $\begin{array}{l}\text { https://www.tokopedia.co } \\
\text { m/blueonekomputer }\end{array}$ & 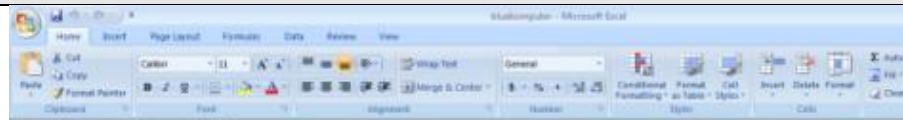 \\
\hline & & 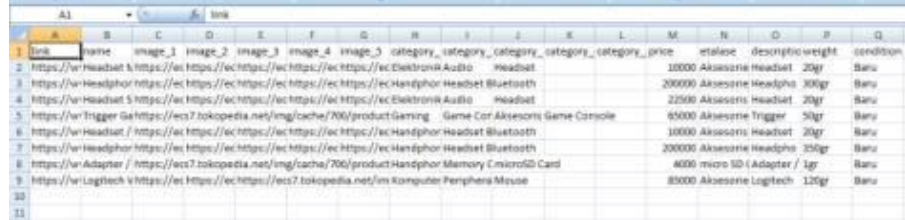 \\
\hline
\end{tabular}

2 https://www.tokopedia.co $\mathrm{m} /$ hokiolshop

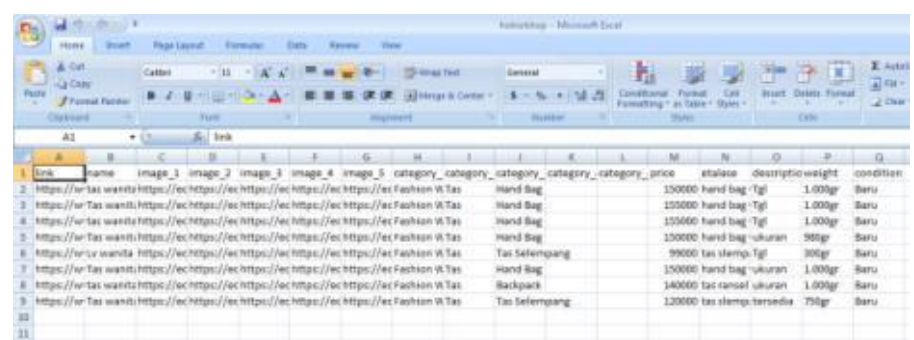

3 https://www.tokopedia.co $\mathrm{m} /$ cafana? source $=$ universe $\&$ st=product

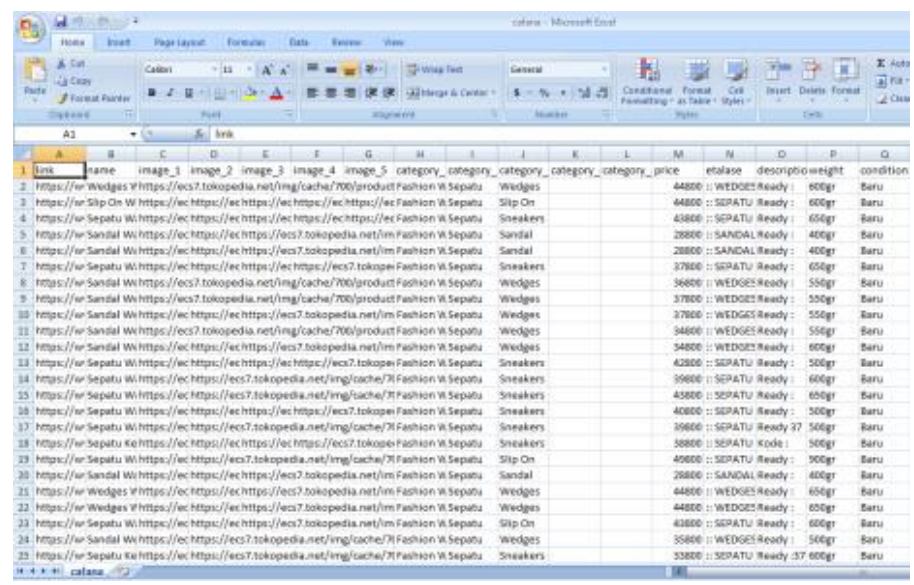

4 https://www.tokopedia.co m/cakarcs

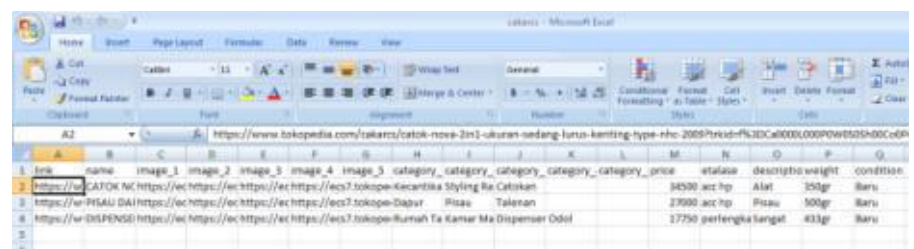

5 https://www.tokopedia.co $\mathrm{m} / \mathrm{dneos}$

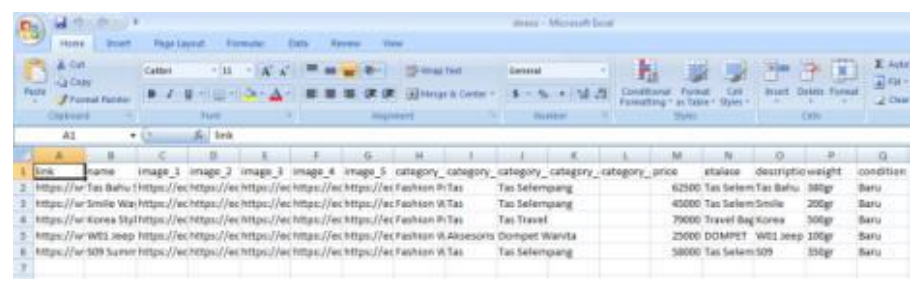




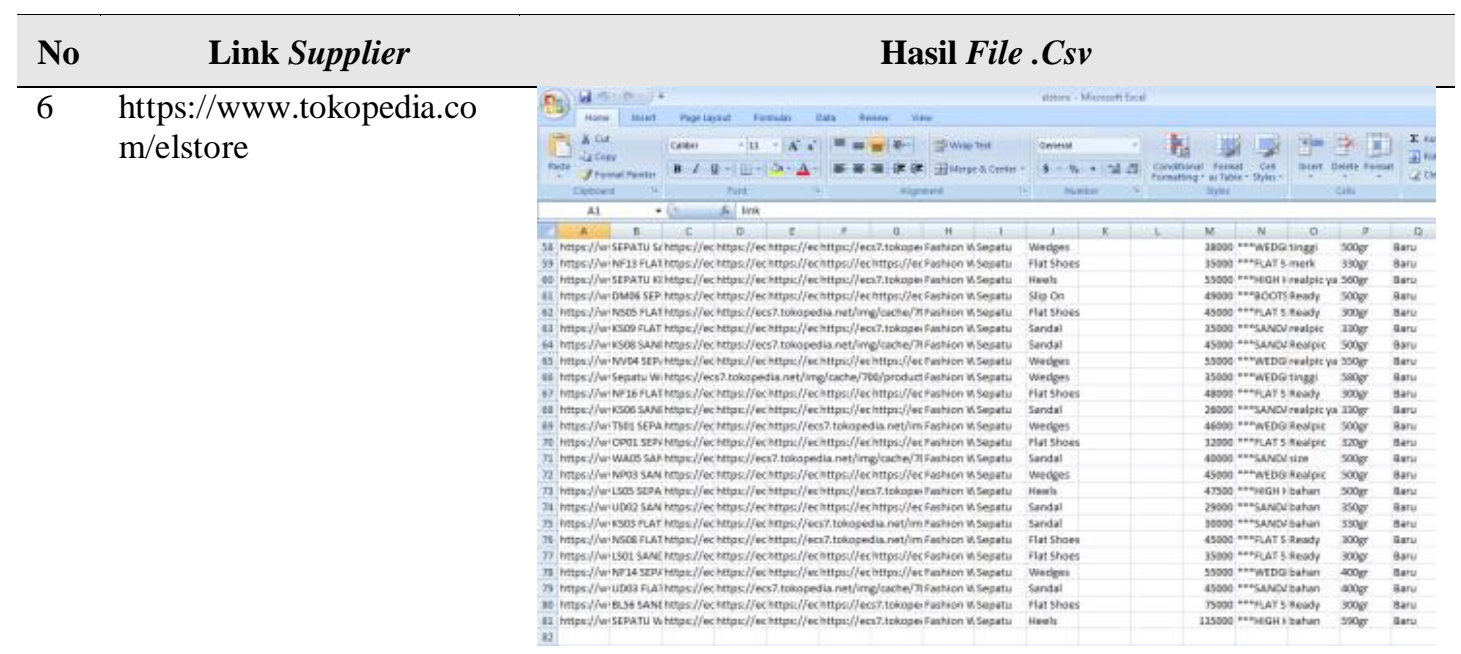

7 https://www.tokopedia.co $\mathrm{m} /$ pastibagusshop

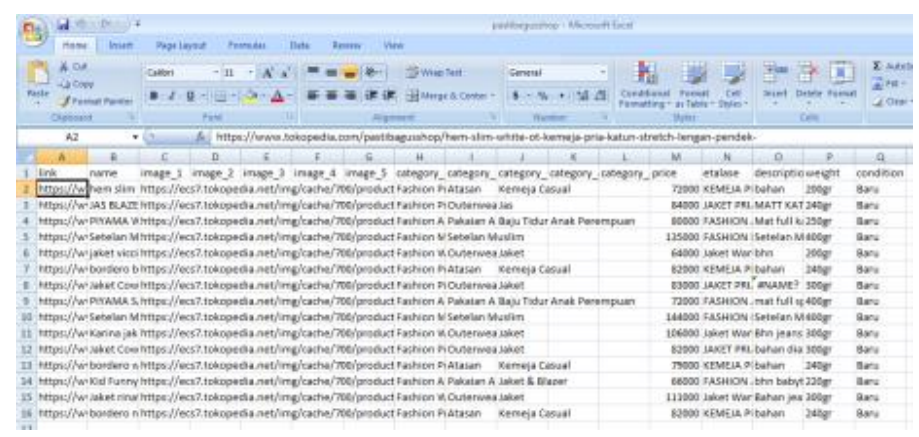

8 https://www.tokopedia.co m/tipani-shop/etalase/boot

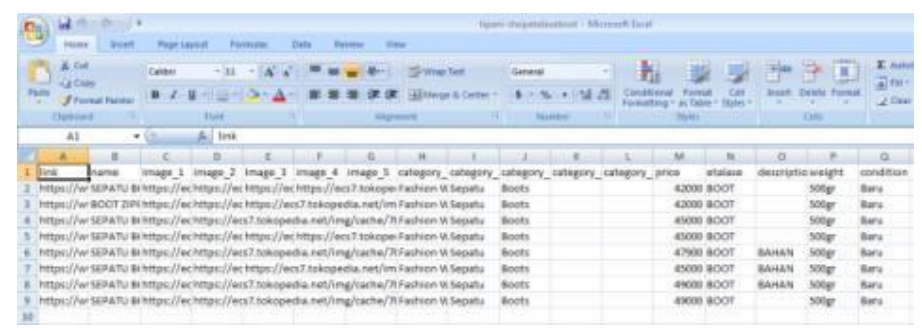

9 https://www.tokopedia.co $\mathrm{m} /$ tipanishop/etalase/flatshoes-1

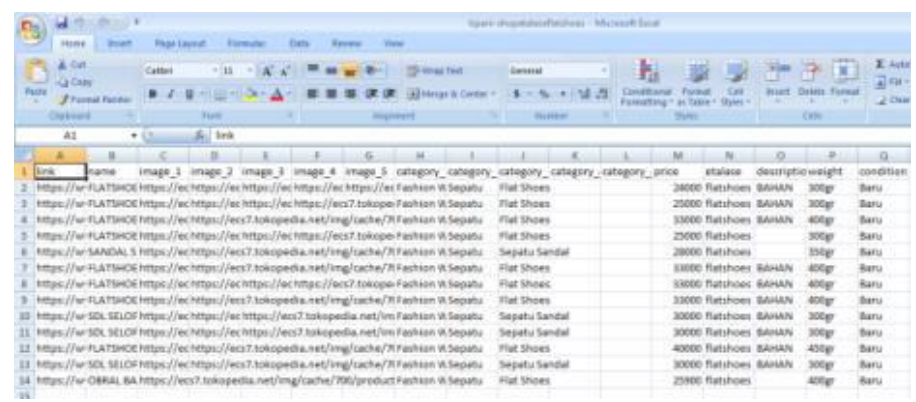




\begin{tabular}{|c|c|c|c|}
\hline No & Link Supplier & Hasil File .Csv & \\
\hline 10 & $\begin{array}{l}\text { https://www.tokopedia.co } \\
\text { m/tipani-shop/etalase/high- } \\
\text { heels-1 }\end{array}$ & 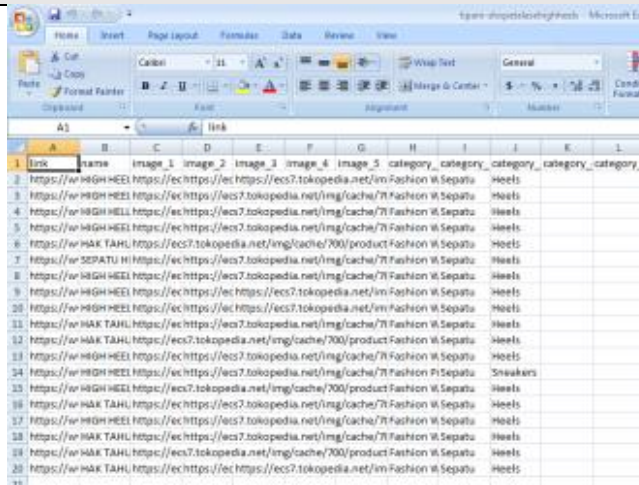 & 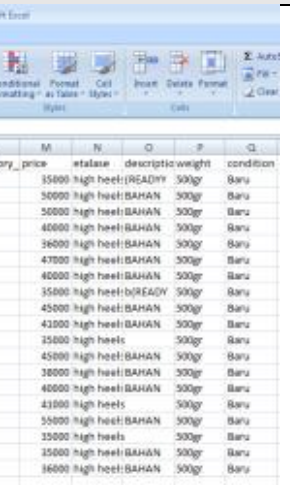 \\
\hline
\end{tabular}

\section{Pengujian Upload}

Pengujian upload dilakukan menggunakan toko drop shipper afrizal22hop pada marketplace Shopee dan e-commerce Afrizal22hop.

Tabel 2. Pengujian Upload

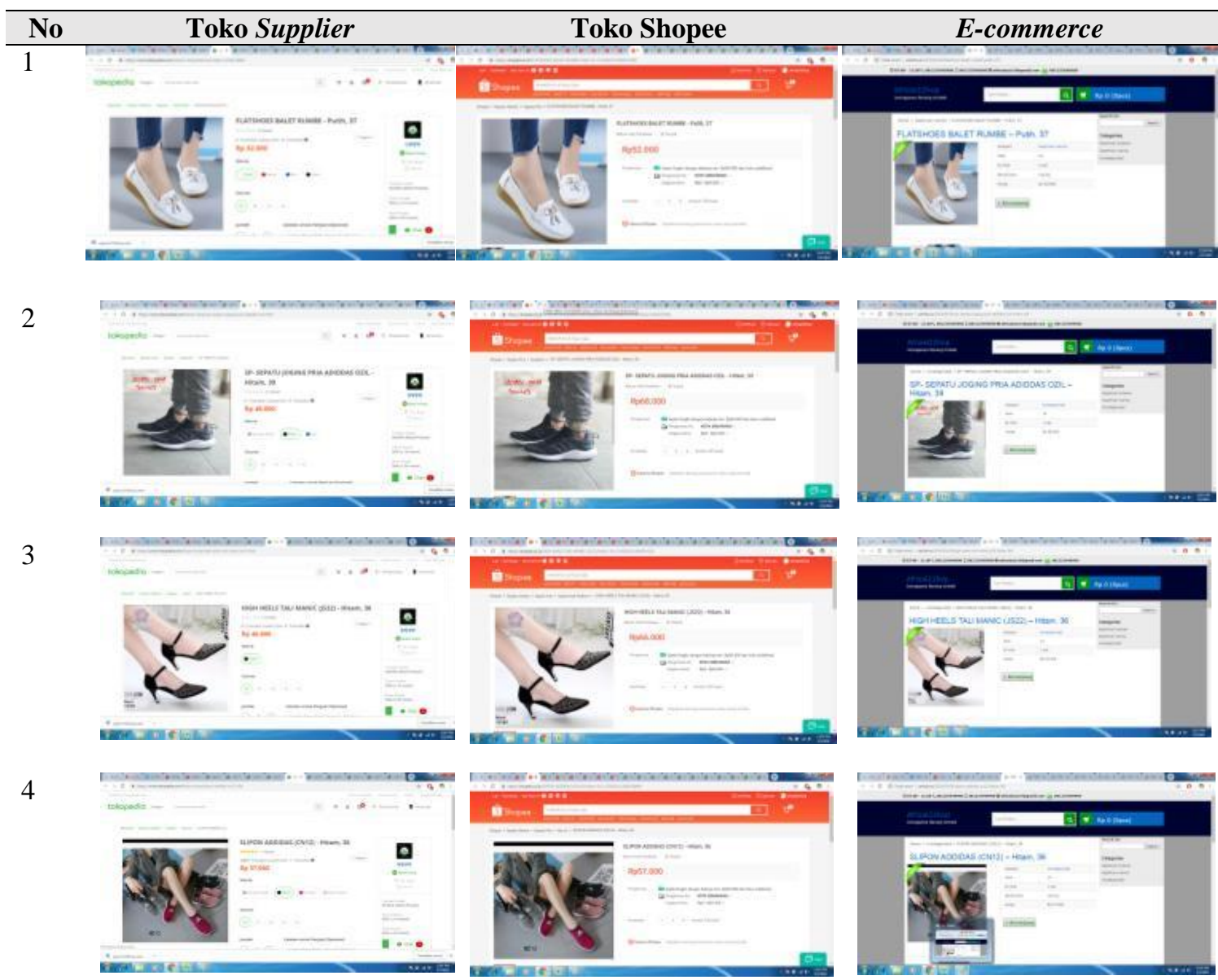




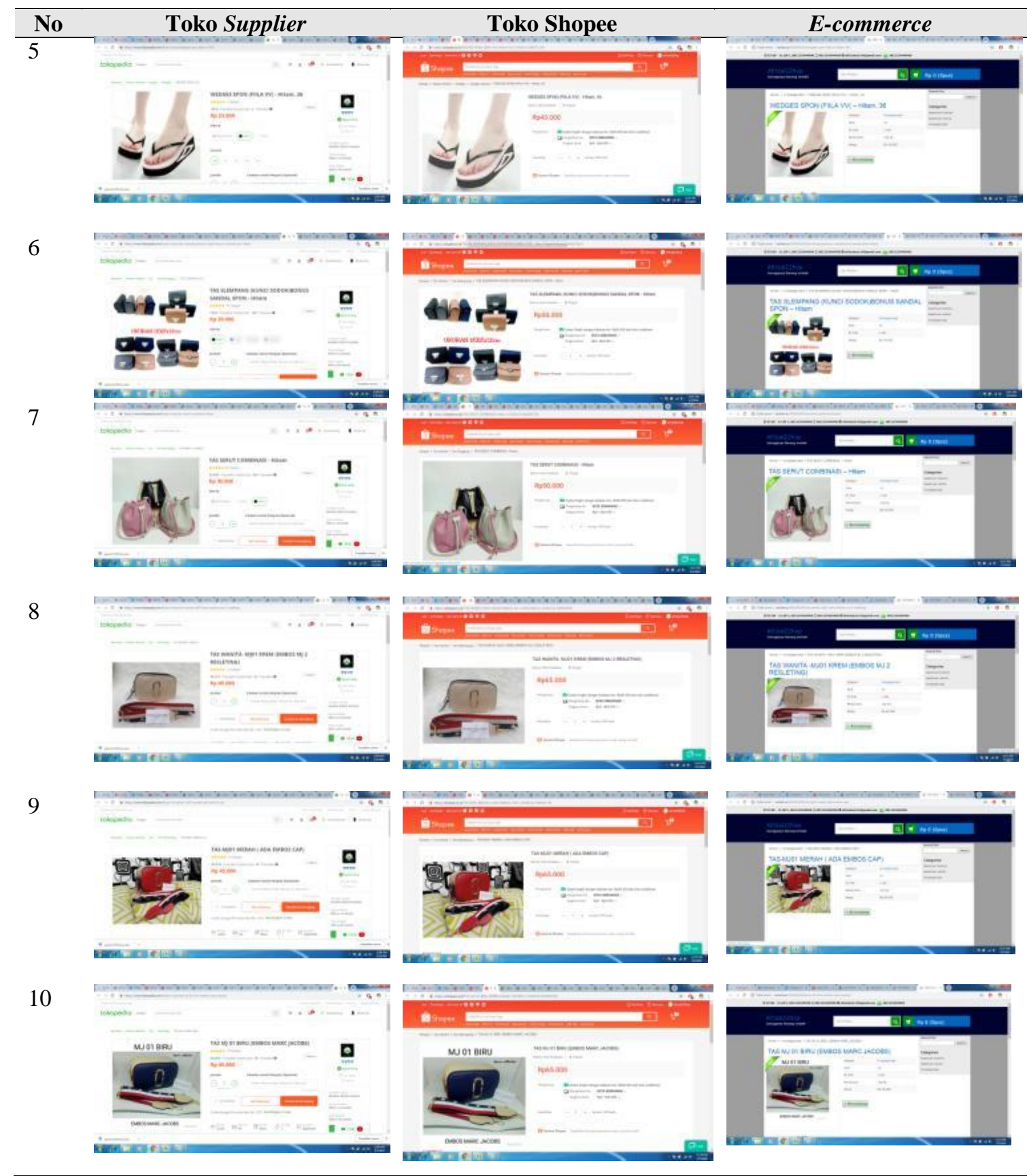

\section{KESIMPULAN}

Dengan terciptanya aplikasi web scraping dan auto upload pada marketplace sudah dapat digunakan drop shipper untuk men-scrape atau mengambil data barang, mengubah harga sesuai keinginan drop shipper, dan meng-upload kembali hasil scrape ke toko drop shipper yang telah diuji keberhasilannya pada marketplace Tokopedia, Shopee dan e-commerce Afrizal22hop.

\section{DAFTAR PUSTAKA}

[1] I. Worldstats, "Top 20 Countries With The Highest Number of Internet Users," Internet

Journal of Information System Vol. 4, No. 1, Mei 2019, hlm. 41-53 
Worldstats, 2018. [Online]. Available: https://www.internetworldstats.com/top20.htm. [Accessed: 23-Apr-2019].

[2] A. Susanto, Wijanarto, and I. Utomo WM, "Rekayasa E-Market untuk Kelompok Usaha Pemuda Binaan Dinas Pemuda Dan Olahraga Propinsi Jawa Tengah sebagai upaya Peningkatan Pemasaran dan Penjualan Produk UMKM," pp. 251-258, 2014.

[3] D. Irmawati, "Pemanfaatan E-Commerce Dalam Dunia Bisnis," J. Ilm. Orasi Bisnis ISSN 2085-1375, no. VI, pp. 95-112, 2011.

[4] S. Haryanti and T. Irianto, "Rancang Bangun Sistem Informasi E-Commerce Untuk Usaha Fashion Studi Kasus Omah Mode Kudus," J. Speed - Sentra Penelit. Eng. dan Edukasi, vol. 3, no. 1, pp. 8-14, 2011.

[5] A. Susanto and F. Budiman, "Rekayasa Model Internet Marketing Pada E-Supermuseum Batik Untuk Meningkatkan Pemasaran Batik Produk Unggulan Ukm Batik Di Jawa Tengah," Semin. Nas. Inform. Yogyakarta, vol. 2013, no. semnasIF, pp. 1979-2328, 2013.

[6] A. K. Saeful Fahmi, "Rancang Bangun E-Marketplace Dengan Model Prototyping Pada Dinas Koperasi Dan Umkm Provinsi Jawa Tengah,” pp. 1-9, 2017.

[7] J. Sundari and E. R. Nainggolan, "E-Marketplace Desa Gerabah Untuk Pengrajin Di Desa Bumi Jaya Serang Banten,” J. Ind. Serv. Vol. 3 No. la Oktober 2017, vol. 3, no. 1, pp. 6873, 2017.

[8] D. H. Bima Prabowo, Ery Agus Priyono, "Diponegoro law journal," Diponegoro Law J., vol. 5, no. 3, pp. 1-13, 2017.

[9] M. S. A. Dzikrulloh, S. E. I., "Jual Beli Dropshipping dalam Bisnis Online," Anim. Genet., vol. 39, no. 5, pp. 561-563, 2018.

[10] Shopping Cart Elite, "Web Scraping and Data Collection for Online Retail Shops (ecommerce)," 2019. [Online]. Available: https://www.shoppingcartelite.com/articles/webscraping-and-data-collection. [Accessed: 24-Mar-2019].

[11] F. Maria Rosario B, Yovi Pratama, "Penerapan Web Scraping Pada Website Company Profile," Kntia, vol. 4, no. 4, pp. 37-43, 2017.

[12] S. Mahajan and N. Kumar, "A Web Scraping Approach in Node.js," vol. 4, no. April, pp. 909-912, 2015.

[13] A. Priyanto and M. R. Ma'arif, "Implementasi Web Scrapping dan Text Mining untuk Akuisisi dan Kategorisasi Informasi dari Internet (Studi Kasus: Tutorial Hidroponik)," Indones. J. Inf. Syst., vol. 1, no. 1, pp. 25-33, 2018.

[14] R. C. Wijaya, J. Andjarwirawan, and H. N. Palit, "Aplikasi Pencarian Produk Jual Mobile Devices dari Berbagai Situs E-commerce,” J. Infra, vol. 4, no. 1, p. pp.180-p.185, 2016.

[15] R. Schnell and S. Redlich, "Web Scraping Online Newspaper Death Notices for the Estimation of the Local Number of Deaths," Proc. 12th Int. Jt. Conf. Biomed. Eng. Syst. Technol., pp. 319-325, 2019.

[16] I. Sommerville, Software Engineering (Rekayasa Perangkat Lunak). Jakarta: Erlangga, 2011.

[17] Laravel, "Laravel Dusk," 2019. [Online]. Available: https://laravel.com/docs/5.8/dusk. [Accessed: 24-Mar-2019]. 